\title{
Synthesis and characterization five-coordinate molybdenum compounds bearing bi- or tridentate substituted pyrrole ligands: molecular structures of $\left\{\mathrm{Mo}\left(\mathrm{NC}_{6} \mathrm{H}_{3} \mathrm{Pr}_{2}^{\mathrm{i}}-2,6\right)_{2} \mathrm{R}\left[\mathrm{NC}_{4} \mathrm{H}_{3}\left(\mathrm{CH}_{2} \mathrm{NMe}_{2}\right)-2\right]\right\}$ and $\left\{\mathrm{Mo}\left(\mathrm{NC}_{6} \mathrm{H}_{3} \mathrm{Pr}_{2}^{\mathrm{i}}-2,6\right)_{2} \mathrm{Cl}\left[\mathrm{NC}_{4} \mathrm{H}_{2}\left(\mathrm{CH}_{2} \mathrm{NMe}_{2}\right)_{2}-2,5\right]\right\}$, where $\mathrm{R}=\mathrm{Cl}$, $\mathrm{Me}, \mathrm{Bu}$
}

\author{
Jui-Hsien Huang a,*, Hsing-Jen Chen a, Chung-Ching Hsieh a, Gene-Hsiang Lee ${ }^{\mathrm{b}}$, \\ Shie-Ming Peng ${ }^{b}$ \\ a Department of Chemistry, National Changhua University of Education, Changhua 500, Taiwan, ROC \\ ${ }^{\mathrm{b}}$ Department of Chemistry, National Taiwan University, Taipei 106, Taiwan, ROC
}

Received 1 March 2001; accepted 13 June 2001

\begin{abstract}

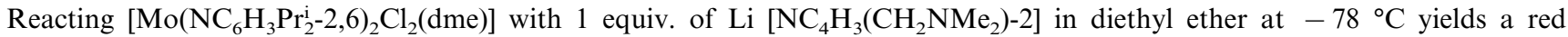
crystalline solid of $\left\{\mathrm{Mo}\left(\mathrm{NC}_{6} \mathrm{H}_{3} \mathrm{Pr}_{2}^{\mathrm{i}}-2,6\right){ }_{2} \mathrm{Cl}\left[\mathrm{NC}_{4} \mathrm{H}_{3}\left(\mathrm{CH}_{2} \mathrm{NMe}_{2}\right)-2\right]\right\} 1$ in $86 \%$ yield. Alkylation of 1 with $\mathrm{RLi}$ in diethyl ether generates $\left\{\mathrm{Mo}\left(\mathrm{NC}_{6} \mathrm{H}_{3} \mathrm{Pr}_{2}^{\mathrm{i}}-2,6\right)_{2} \mathrm{R}\left[\mathrm{NC}_{4} \mathrm{H}_{3}\left(\mathrm{CH}_{2} \mathrm{NMe}_{2}\right)-2\right]\right\} \quad(\mathbf{2 a}, \quad \mathrm{R}=\mathrm{Me} ; \quad \mathbf{2 b}, \quad \mathrm{R}=\mathrm{Bu})$ in high yield. Similarly, reacting $\left[\mathrm{Mo}\left(\mathrm{NC}_{6} \mathrm{H}_{3} \mathrm{Pr}_{2}^{\mathrm{i}}-2,6\right)_{2} \mathrm{Cl}_{2}(\mathrm{dme})\right]$ with 1 equiv. of $\mathrm{Li}\left[\mathrm{NC}_{4} \mathrm{H}_{2}\left(\mathrm{CH}_{2} \mathrm{NMe}_{2}\right)_{2}-2,5\right]$ in diethyl ether at $-78{ }^{\circ} \mathrm{C}$ affords dark red crystals of $\left\{\mathrm{Mo}\left(\mathrm{NC}_{6} \mathrm{H}_{3} \mathrm{Pr}_{2}^{\mathrm{i}}-2,6\right)_{2} \mathrm{Cl}\left[\mathrm{NC}_{4} \mathrm{H}_{2}\left(\mathrm{CH}_{2} \mathrm{NMe}_{2}\right)_{2}-2,5\right]\right\} 3$ in $92 \%$ yield, in which one $\mathrm{NMe}_{2}$ unit of the pyrrole ligand of 3 coordinates to molybdenum whilst the other one dangles outside the coordination sphere. Variable-temperature ${ }^{1} \mathrm{H}$ NMR study of 3 reveals fluxional behavior of the two $\mathrm{NMe}_{2}$ units of the pyrrole ligand. The activation energy of the fluxionality has been determined as $\Delta G^{\neq}=10.5 \mathrm{kcal} \mathrm{mol}^{-1}$. Compounds 1, 2a, $\mathbf{2 b}$ and $\mathbf{3}$ have been characterized by NMR spectroscopy and X-ray crystallography. (C) 2001 Elsevier Science B.V. All rights reserved.
\end{abstract}

Keywords: Pyrrole; Five coordinate; Molybdenum compounds; Bidentate; Tridentate

\section{Introduction}

Transition metal imido complexes have been widely studied because of their applications in the mechanistic study of the Haber ammonia synthesis [1], the reduction of nitrile [2], and the ammoxidation of propylene [3]. The reactivity of metal imido complexes depends on metals and their oxidation state, auxiliary ligands, and the nature of the substituents on nitrogen [4]. In addition, $\mathrm{d}^{0}$ bis-imido metal complexes $(\mathrm{RN}=)_{2} \mathrm{M}(\mathrm{VI})(\mathrm{M}=$

\footnotetext{
* Corresponding author. Tel.: +886-4-723 2105x3531; fax: +8864-721 1190.

E-mail address: juihuang@cc.ncue.edu.tw (J.-H. Huang).
}

Mo, W) have been treated as isolobal of biscyclopentadienyl metal complexes, $\mathrm{Cp}_{2} \mathrm{M}(\mathrm{IV})(\mathrm{M}=\mathrm{Ti}, \mathrm{Zr})$ [5]. We are interested in finding new bis-imido molybdenum complexes bearing bi- or tridentate auxiliary ligands, which may provide new metal complexes with unusual properties due to the steric and electronic effects. 2-(Dimethylaminomethyl)pyrrole and 2,5-bis(dimethylaminomethyl)pyrrole [6] had been synthesized in the late 1940s, however, very limited compounds bearing these types of ligands had been synthesized [7].

Metals involved in this series of chemistry, such as $\mathrm{d}^{0}$ early transition metals [8] and Group 13 elements [9], have been reported. We report herein the synthesis and structural characterization of bis-imido molybdenum complexes bearing the bi- or tridentate substituted 
pyrrole ligands along with their alkylation reactions and the results of dynamic studies by variable-temperature ${ }^{1} \mathrm{H}$ NMR.

\section{Results and discussion}

\subsection{Synthesis and characterization}

The reactions of this study are summarized in Scheme 1. Reacting [Mo( $\left.\left.\mathrm{NC}_{6} \mathrm{H}_{3} \mathrm{Pr}_{2}^{\mathrm{i}}-2,6\right)_{2} \mathrm{Cl}_{2}(\mathrm{dme})\right]$ [10] with 1 equiv. of $\mathrm{Li}\left[\mathrm{NC}_{4} \mathrm{H}_{3}\left(\mathrm{CH}_{2} \mathrm{NMe}_{2}\right)-2\right]$ in diethyl ether at $-78{ }^{\circ} \mathrm{C}$ affords a red crystalline solid of $\mathrm{Mo}\left(\mathrm{NC}_{6} \mathrm{H}_{3} \mathrm{Pr}_{2}^{\mathrm{i}}-2,6\right)_{2} \mathrm{Cl}\left[\mathrm{NC}_{4} \mathrm{H}_{3}\left(\mathrm{CH}_{2} \mathrm{NMe}_{2}\right)-2\right]$ (1), which can be isolated in $86 \%$ yield. Alternatively, compound $\mathbf{1}$ can be prepared directly from $\left[\mathrm{Mo}\left(\mathrm{NC}_{6} \mathrm{H}_{3} \mathrm{Pr}_{2}^{\mathrm{i}}-\right.\right.$ $\left.2,6)_{2} \mathrm{Cl}_{2}(\mathrm{dme})\right]$ in $81 \%$ yield by treating it with 1 equiv. of $\left[\mathrm{HNC}_{4} \mathrm{H}_{3}\left(\mathrm{CH}_{2} \mathrm{NMe}_{2}\right)-2\right]$ in diethyl ether at room temperature. The ${ }^{1} \mathrm{H}$ NMR spectrum of compound $\mathbf{1}$ in $\mathrm{CDCl}_{3}$ has one singlet resonance at $2.95 \mathrm{ppm}$ for $\mathrm{NMe}_{2}$ and one singlet resonance at $4.22 \mathrm{ppm}$ for $\mathrm{CH}_{2} \mathrm{~N}$, which are downfield shifting while comparing with that of free ligand, $\left[\mathrm{HNC}_{4} \mathrm{H}_{3}\left(\mathrm{CH}_{2} \mathrm{NMe}_{2}\right)\right.$-2], indicating the high oxidation state of molybdenum depletes electrons density from the substituted pyrrole ligand. The two phenylimido groups exhibit equivalent magnetic environment as evidenced by the observation of one isopropyl methine hydrogen resonance at $3.40 \mathrm{ppm}$.

Alkylation of 1 with $\mathrm{RLi}$ in diethyl ether at $-78^{\circ} \mathrm{C}$ generates $\left\{\mathrm{Mo}\left(\mathrm{NC}_{6} \mathrm{H}_{3} \mathrm{Pr}_{2}^{\mathrm{i}}-2,6\right)_{2} \mathrm{R}\left[\mathrm{NC}_{4} \mathrm{H}_{3}\left(\mathrm{CH}_{2} \mathrm{NMe}_{2}\right)\right.\right.$ 2]) $(\mathbf{2 a}, \mathrm{R}=\mathrm{Me} ; \mathbf{2} \mathbf{b}, \mathrm{R}=\mathrm{Bu})$ in high yield (81 and $88 \%$ ). The ${ }^{1} \mathrm{H}$ NMR spectrum of $2 \mathrm{a}$ reveals a singlet at $1.14 \mathrm{ppm}$ for the Mo-methyl group with $J_{\mathrm{CH}}$ coupling constant at ca. $126 \mathrm{~Hz}$, showing no $\alpha$-agostic interaction between molybdenum and methyl $\mathrm{C}-\mathrm{H}$ bonds in solution [11]. The ${ }^{1} \mathrm{H}$ NMR spectrum of $\mathrm{Mo}-\mathrm{Bu}$ of $\mathbf{2 b}$ shows more complicated chemical shifts than the methyl group of $\mathbf{2 a}$, in which three resonances are observed at $1.89,1.25$ and $0.85 \mathrm{ppm}$ with integration of $4 \mathrm{H}, 2 \mathrm{H}$ and $3 \mathrm{H}$, respectively. Homonuclear decoupling and ${ }^{1} \mathrm{H}-{ }^{13} \mathrm{C}$ 2-D NMR spectra of $\mathbf{2} \mathbf{b}$ in $\mathrm{CDCl}_{3}$ show that the $\alpha$ and $\beta$ protons of the butyl group are coupled together and appear as a broad single band at $1.8 \mathrm{ppm}$ while $\gamma$ and $\delta$ protons appear at 1.25 and $0.85 \mathrm{ppm}$, respectively. It is worth noting that to our knowledge, compound $\mathbf{2 b}$ is the first isolated bis-imido molybdenum compound containing a butyl ligand. The common alkylating reagents used in the literature usually lack either $\beta$-hydrogen or co-planar conformation of Mo-C-C-H such as methyl, neopentyl, silyl, or metallocyclopentane etc. [11,12].

Similarly, reacting $\left[\mathrm{Mo}\left(\mathrm{NC}_{6} \mathrm{H}_{3} \mathrm{Pr}_{2}^{\mathrm{i}}-2,6\right)_{2} \mathrm{Cl}_{2}(\mathrm{dme})\right]$ with 1 equiv. of $\mathrm{Li}\left[\mathrm{NC}_{4} \mathrm{H}_{2}\left(\mathrm{CH}_{2} \mathrm{NMe}_{2}\right)_{2}-2,5\right]$ in diethyl ether at $-78{ }^{\circ} \mathrm{C}$ affords dark red crystals of $\left\{\mathrm{Mo}\left(\mathrm{NC}_{6} \mathrm{H}_{3} \mathrm{Pr}_{2}^{\mathrm{i}}-2,6\right)_{2} \mathrm{Cl}\left[\mathrm{NC}_{4} \mathrm{H}_{2}\left(\mathrm{CH}_{2} \mathrm{NMe}_{2}\right)_{2}-2,5\right]\right\} \quad$ (3), which was isolated in $92 \%$ yield. ${ }^{1} \mathrm{H}$ NMR spectrum of compound 3 in $\mathrm{CDCl}_{3}$ at room temperature shows only one resonance for $\mathrm{NMe}_{2}$ units indicating the two $\mathrm{NMe}_{2}$ units of $\left[\mathrm{NC}_{4} \mathrm{H}_{2}\left(\mathrm{CH}_{2} \mathrm{NMe}_{2}\right)_{2}-2,5\right]$ ligand are either fast exchanging at room temperature in solution or magnetically equivalent. Variable-temperature ${ }^{1} \mathrm{H}$ NMR spectra of compound 3 in $\mathrm{CDCl}_{3}$ using $600 \mathrm{MHz} \mathrm{NMR}$ were taken in order to resolve the ambiguity and the region of the $\mathrm{NMe}_{2}$ resonances are depicted in Fig. 1.

Two resonances of the $\mathrm{NMe}_{2}$ of the pyrrole ligand at 2.58 and $1.90 \mathrm{ppm}$ were observed at $213 \mathrm{~K}$ with broad-

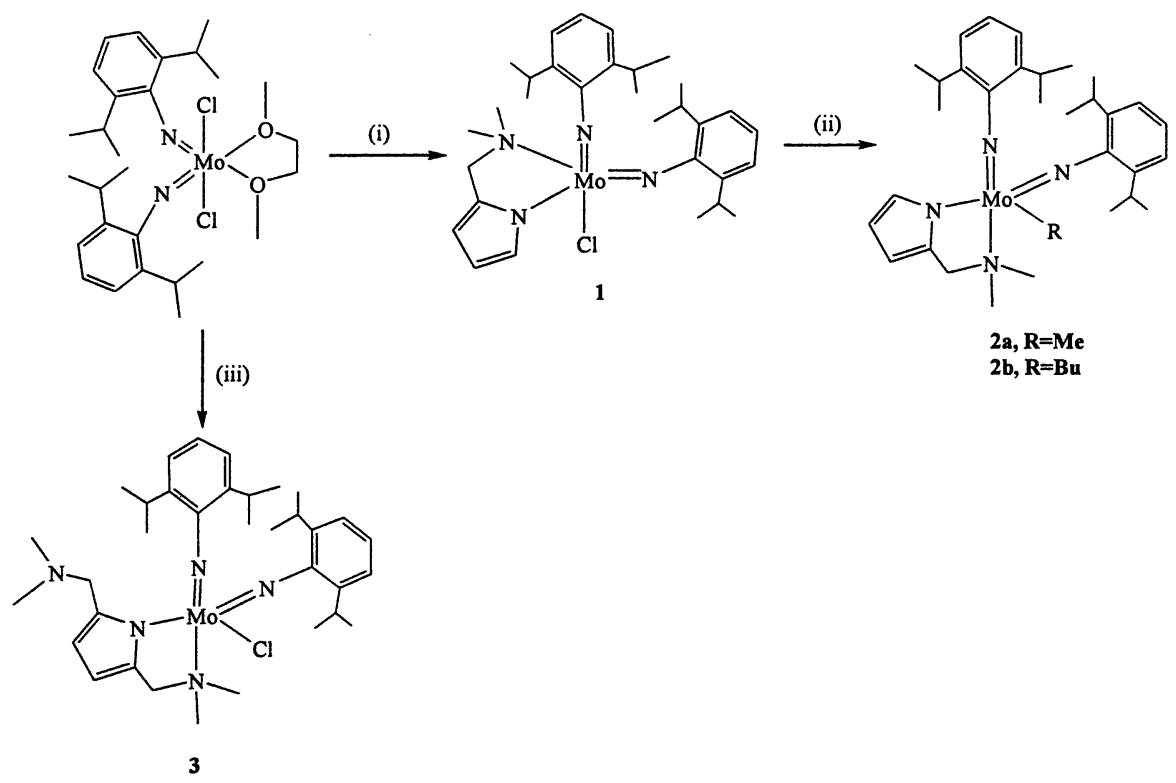

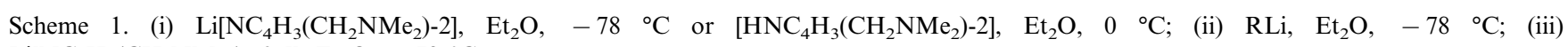
$\mathrm{Li}\left[\mathrm{NC}_{4} \mathrm{H}_{2}\left(\mathrm{CH}_{2} \mathrm{NMe}_{2}\right)_{2}-2,5\right], \mathrm{Et}_{2} \mathrm{O},-78{ }^{\circ} \mathrm{C}$. 


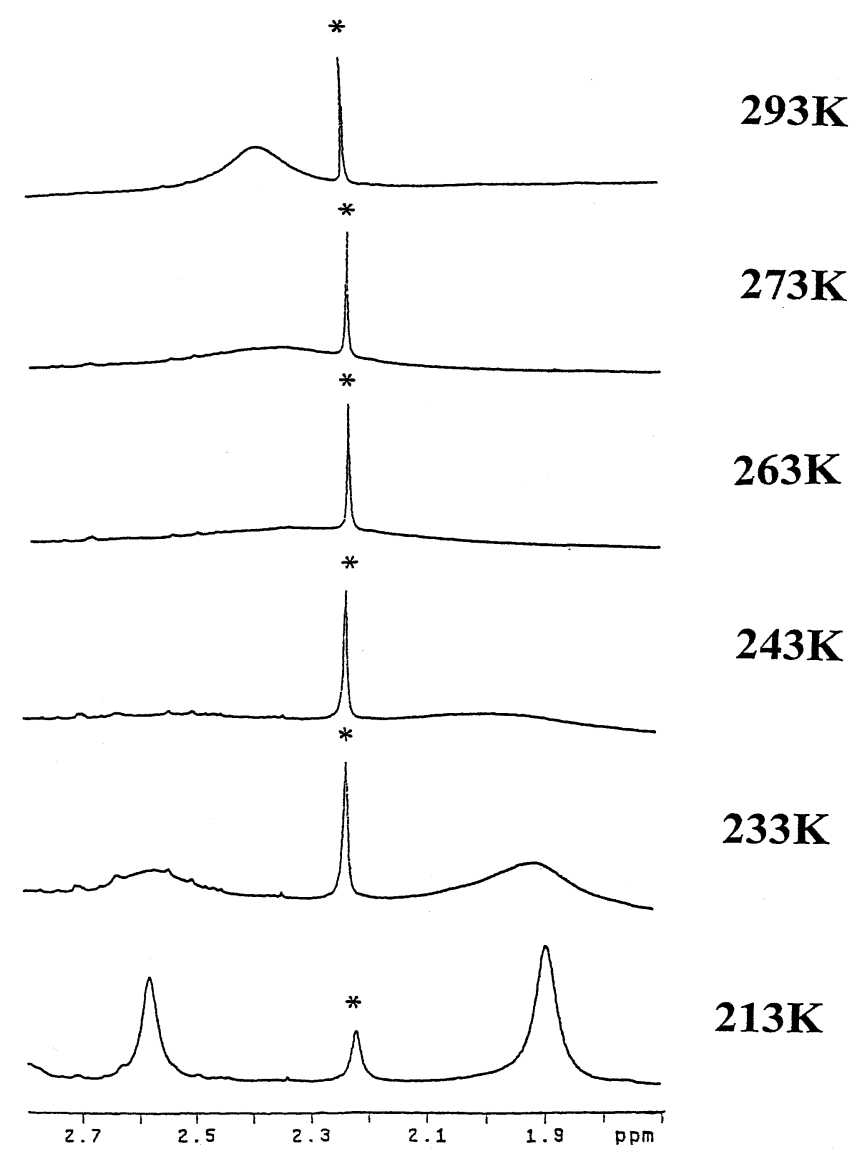

Fig. 1. The variable-temperature ${ }^{1} \mathrm{H}$ NMR. spectra of compound 3 in $\mathrm{CDCl}_{3}$ at $600 \mathrm{MHz} \mathrm{NMR}$ spectrometer. The range of $\delta 2.8-1.7$ is drawn showing the resonance of $\mathrm{NMe}_{2}$ of pyrrole. The impurity is marked with asterisks.

ening as the temperature raised, and coalescence was observed at ca. $253 \mathrm{~K}$. A single resonance at $2.38 \mathrm{ppm}$ was obtained while the temperature of the NMR sample was raised to room temperature. The activation energy, $\Delta G^{\neq}$, for fluxionality calculated using the chemical shift differences of the proton resonances in the slow limit, is estimated at ca. $10.5 \mathrm{kcal} \mathrm{mol}^{-1}$.

\subsection{Solid state structure determination}

\subsubsection{Molecular structure of}

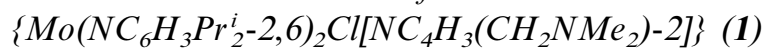

Deep red crystals of 1 suitable for structure determination were grown from a saturated diethyl ether solution at $-20{ }^{\circ} \mathrm{C}$. Data collection and selected bond distances and angles are shown in Tables 1 and 2, respectively. An ORTEP drawing of compound $\mathbf{1}$ is depicted in Fig. 2. The coordination geometry of $\mathbf{1}$ is best described as a distorted trigonal bipyramidal with one $\mathrm{NMe}_{2}$ and one imido taking axial positions $\left[\mathrm{N}(2)-\mathrm{Mo}-\mathrm{N}(3)\right.$ at $\left.152.34(7)^{\circ}\right]$ with the other imido ligand, chloride and pyrrole in the equatorial plane [the sum of angles of $\mathrm{Cl}-\mathrm{Mo}-\mathrm{N}(4), \mathrm{N}(4)-\mathrm{Mo}-\mathrm{N}(1)$, and $\mathrm{Cl}$
$-\mathrm{Mo}-\mathrm{N}(1)$ is ca. $354^{\circ}$. The deviation of the axial position from the linear $\mathrm{N}(2)-\mathrm{Mo}-\mathrm{N}(3)$ bond may result from the constrained bond angle of $\left[\mathrm{NC}_{4} \mathrm{H}_{3}-\right.$ $\left.\left(\mathrm{CH}_{2} \mathrm{NMe}_{2}\right)-2\right]$. The two imido ligands are substantially different and characterized as linear and bent imido with the bond angles of $\mathrm{Mo}-\mathrm{N}(3)-\mathrm{C}(8)$ and Mo-N(4)-C(20) being at $175.13(14)$ and $147.55(14)^{\circ}$, respectively. However, the two bond distances of Mo-N(3) and Mo-N(4) fall at the same range and similar results have also been observed in the literature as shown in Table 3. Two aspects can be attributed to the phenomena: (i) The two imido ligands are magnetically equivalent in the NMR time scale, the different Mo-N-C angles indicating the Mo-N bonds are best described as 2.5 [16]. (ii) The phenyl ring of equatorial imido bends toward the axial imido ligand, which can be rationalized as the steric interaction of lone pair electrons on the nitrogen with the dimethylamino part of the pyrrole ligand.

\subsubsection{Molecular structures of $\left\{\mathrm{Mo}\left(\mathrm{NC}_{6} \mathrm{H}_{3} \mathrm{Pr}_{2}^{i}-2,6\right)_{2}\right.$ - $\left.\mathrm{Me}\left[\mathrm{NC}_{4} \mathrm{H}_{3}\left(\mathrm{CH}_{2} \mathrm{NMe}_{2}\right)-2\right]\right\}$ (2a) and \\ $\left\{\mathrm{Mo}\left(\mathrm{NC}_{6} \mathrm{H}_{3} \mathrm{Pr}_{2}^{i}-2,6\right)_{2} \mathrm{Bu}\left[\mathrm{NC}_{4} \mathrm{H}_{3}\left(\mathrm{CH}_{2} \mathrm{NMe}_{2}\right)-2\right]\right\}$ (2b)}

Crystals of $\mathbf{2 a}$ and $\mathbf{2 b}$ are both obtained from saturated diethyl ether solution at $-20^{\circ} \mathrm{C}$. Data collection and selected bond distances and angles are shown in Tables 1 and 2, and ORTEP drawings of compounds $\mathbf{2 a}$ and $\mathbf{2 b}$ are depicted in Figs. 3 and 4, respectively. The molecular structures of $\mathbf{2 a}$ and $\mathbf{2} \mathbf{b}$ are both similar to that of $\mathbf{1}$ and can be described as distorted trigonal bipyramidal with the bond angles of axial ligands at $151.8(2)$ and $156.18(12)^{\circ}$ for $\mathbf{2 a}$ and $\mathbf{2 b}$, respectively. Note the sum of the equatorial angles of 2a $\left(353.5^{\circ}\right)$ and $\mathbf{2 b}\left(353.9^{\circ}\right)$ are close to $360^{\circ}$ and the bond distances for Mo to imido ligands are in the same range as for $\mathbf{1}$. The bond distance for Mo-alkyl, i.e. Mo-C(32) 2.219(6) $\AA$ for compound 2a and Mo-C(32) 2.169(3) $\AA$ for compound $\mathbf{2 b}$, are in the short end when compared with other bond distances of Mo-alkyl [12].

\subsubsection{Molecular structure of}

$\left\{\mathrm{Mo}\left(\mathrm{NC}_{6} \mathrm{H}_{3} \mathrm{Pr}_{2}{ }_{2}-2,6\right)_{2} \mathrm{Cl}\left[\mathrm{NC}_{4} \mathrm{H}_{2}\left(\mathrm{CH}_{2} \mathrm{NMe}_{2}\right)_{2}-2,5\right]\right\}$ (3)

Deep red crystals are obtained from saturated diethyl ether solution of compound 3 at $-20{ }^{\circ} \mathrm{C}$. Crystal data collections are summarized in Table 1 and selected bond distances and angles are listed in Table 2. An ORTEP drawing of compound $\mathbf{3}$ is shown in Fig. 5. Comparing the solid state structures of compounds 1 and $\mathbf{3}$, the bond distances and angles related to the molybdenum center are quite similar. Compound 3 can be described as a distorted trigonal bipyramid with pyrrole, chloride, and phenylimido ligand taking the trigonal plane positions. The other phenylimido and one of the two $\mathrm{NMe}_{2}$ of the pyrrole ligand occupied the axial positions with a bond angle of $156.03(7)^{\circ}$, while the other $\mathrm{NMe}_{2}$ of the pyrrole ligand dangles outside the coordinating sphere. 


\section{Experimental}

All the reactions were performed using standard Schlenk techniques in an atmosphere of high purity nitrogen or in a glove box. Ethyl ether and heptane were dried over $\mathrm{Na}$ /benzophenone ketyl and distilled before use. Methylene chloride was dried over $\mathrm{P}_{2} \mathrm{O}_{5}$ and distilled prior to use. $\left[\mathrm{Mo}\left(\mathrm{NC}_{6} \mathrm{H}_{3} \mathrm{Pr}_{2}^{\mathrm{i}}-2,6\right)_{2} \mathrm{Cl}_{2}(\mathrm{dme})_{2}\right]$ [10], 2-(dimethylaminomethyl) pyrrole [6], 2,5-bis(dimethylaminomethyl)pyrrole [6], and lithium salt of substituted pyrrole ligand [8] were prepared according to published literatures. $\mathrm{CDCl}_{3}$ was degassed by freezeand-thaw method and dried over $4 \AA$ molecular sieves. ${ }^{1} \mathrm{H}$ and ${ }^{13} \mathrm{C}$ NMR spectra were collected on a Bruker AC200 or Varian 600 instrument. Elemental analysis was performed on Perkin-Elmer CHN-2400.

\subsection{Synthesis}

\subsection{1. $\left\{\mathrm{Mo}\left(\mathrm{NC}_{6} \mathrm{H}_{3} \mathrm{Pr}_{2}^{i}-2,6\right)_{2} \mathrm{Cl}\left[\mathrm{NC}_{4} \mathrm{H}_{3}\left(\mathrm{CH}_{2} \mathrm{NMe}_{2}\right)-2\right]\right\}$} (1)

3.1.1.1. Method A. A $100 \mathrm{ml}$ Schlenk flask was charged with $30 \mathrm{ml}$ of diethyl ether and $\mathrm{Mo}\left(\mathrm{NC}_{6} \mathrm{H}_{3} \mathrm{Pr}_{2}^{\mathrm{i}}-\right.$ $2,6)_{2} \mathrm{Cl}_{2}(\mathrm{dme})(1.50 \mathrm{~g}, 2.5 \mathrm{mmol})$ and cooled to -78
${ }^{\circ} \mathrm{C}$. To this diethyl ether solution, $\left[\mathrm{LiNC}_{4} \mathrm{H}_{3}-\right.$ $\left.\left(\mathrm{CH}_{2} \mathrm{NMe}_{2}\right)-2\right](0.32 \mathrm{~g}, 2.5 \mathrm{mmol})$ in $10 \mathrm{ml}$ diethyl ether was added dropwise. The reaction mixture was warmed to room temperature after the addition was completed and stirred for $14 \mathrm{~h}$. The resulting lithium chloride was removed via filtration and the dark red filtrate was concentrated and cooled to $-20{ }^{\circ} \mathrm{C}$ to yield dark red crystals. Yield $1.28 \mathrm{~g}(86 \%) .{ }^{1} \mathrm{H}$ NMR $\left(\mathrm{CDCl}_{3}\right): \delta 7.08$ (s, 6H, aryl), $6.63(\mathrm{~m}, 1 \mathrm{H}$, pyrrole $), 6.08(\mathrm{~m}, 2 \mathrm{H}$, pyrrole), 4.22 (s, 2H, CH $\mathrm{H}_{2} \mathrm{~N}$ ), 3.40 (sept, $4 \mathrm{H}, \mathrm{CHMe}_{2}$ ), 2.95 (s, 6H, NMe $), 1.03\left(\mathrm{~m}, 24 \mathrm{H}, \mathrm{CHMe}\right.$ ). ${ }^{13} \mathrm{C} \mathrm{NMR}$ $\left(\mathrm{CDCl}_{3}\right): \delta 152.4(\mathrm{~s}), 145.4(\mathrm{~s}), 136.9$ (s), 131.3 (d, $\left.J_{\mathrm{CH}}=183 \mathrm{~Hz}\right), 128.2\left(\mathrm{~d}, J_{\mathrm{CH}}=160 \mathrm{~Hz}\right), 122.4(\mathrm{~d}$, $\left.J_{\mathrm{CH}}=155 \mathrm{~Hz}\right), 110.2\left(\mathrm{~d}, J_{\mathrm{CH}}=163 \mathrm{~Hz}\right), 104.3(\mathrm{~d}$, $\left.J_{\mathrm{CH}}=168 \mathrm{~Hz}\right), 63.5\left(\mathrm{t}, J_{\mathrm{CH}}=138 \mathrm{~Hz}\right), 49.1\left(\mathrm{q}, J_{\mathrm{CH}}=\right.$ $138 \mathrm{~Hz}), 28.3(\mathrm{~d}, 128 \mathrm{~Hz}), 23.8\left(\mathrm{q}, J_{\mathrm{CH}}=126 \mathrm{~Hz}\right), 23.3$ $\left(\mathrm{q}, J_{\mathrm{CH}}=126 \mathrm{~Hz}\right)$. Anal. Found: C, 61.21, H, 7.36, N, 9.26. Calc. for $\mathrm{C}_{31} \mathrm{H}_{45} \mathrm{ClMoN}_{4}$ : C, 61.53; H, 7.50; N, $9.26 \%$.

3.1.1.2. Method B. A $100 \mathrm{ml}$ Schlenk flask charged with $\mathrm{Mo}\left(\mathrm{NC}_{6} \mathrm{H}_{3} \operatorname{Pr}_{2}^{\mathrm{i}}-2,6\right)_{2} \mathrm{Cl}_{2}(\mathrm{dme})(1.5 \mathrm{~g}, 2.5 \mathrm{mmol})$ and $\left[\mathrm{HNC}_{4} \mathrm{H}_{3}\left(\mathrm{CH}_{2} \mathrm{NMe}_{2}\right)-2\right](0.31 \mathrm{~g}, 2.5 \mathrm{mmol})$ was added with $20 \mathrm{ml}$ diethyl ether and stirred for $15 \mathrm{~h}$. The resulting dark red solution was dried under vacuum

Table 1

Crystallographic data for compounds $\mathbf{1}, \mathbf{2 a}, \mathbf{2 b}$, and $\mathbf{3}$

\begin{tabular}{|c|c|c|c|c|}
\hline & 1 & $\mathbf{2 a}$ & $\mathbf{2 b}$ & 3 \\
\hline $\begin{array}{l}\text { Empirical formula } \\
\text { Formula weight }\end{array}$ & $\begin{array}{l}\mathrm{C}_{31} \mathrm{H}_{45} \mathrm{ClMoN}_{4} \\
605.10\end{array}$ & $\begin{array}{l}\mathrm{C}_{32} \mathrm{H}_{48} \mathrm{MoN}_{4} \\
584.68\end{array}$ & $\begin{array}{l}\mathrm{C}_{35} \mathrm{H}_{54} \mathrm{MoN}_{4} \\
626.76\end{array}$ & $\begin{array}{l}\mathrm{C}_{34} \mathrm{H}_{52} \mathrm{ClMoN}_{5} \\
662.20\end{array}$ \\
\hline Temperature $(\mathrm{K})$ & $150(1)$ & $150(1)$ & $150(1)$ & $150(1)$ \\
\hline Wavelength $(\AA)$ & 0.71073 & 0.71073 & 0.71073 & 0.71073 \\
\hline Crystal system & monoclinic & monoclinic & monoclinic & monoclinic \\
\hline Space group & $P 2_{1} / n$ & $P 2_{1} / n$ & $P 2_{1} / c$ & $P 2_{1} / n$ \\
\hline$a(\AA)$ & $10.7802(2)$ & $10.8697(1)$ & $17.7090(2)$ & $11.5402(1)$ \\
\hline$b(\AA)$ & $16.8418(2)$ & $16.7999(1)$ & $10.8807(1)$ & $16.8018(2)$ \\
\hline$c(\AA)$ & $17.1131(3)$ & $17.0008(2)$ & $17.8066(1)$ & $17.9836(1)$ \\
\hline$\beta\left({ }^{\circ}\right)$ & $98.550(1)$ & $97.203(1)$ & $97.776(1)$ & $90.416(1)$ \\
\hline$V\left(\AA^{3}\right)$ & $3072.49(9)$ & $3080.01(5)$ & $3399.54(5)$ & $3486.86(5)$ \\
\hline$Z$ & 4 & 4 & 4 & 4 \\
\hline$D_{\text {calc }}\left(\mathrm{Mg} \mathrm{m}^{-3}\right)$ & 1.308 & 1.261 & 1.225 & 1.261 \\
\hline Absorption coefficient $\left(\mathrm{mm}^{-1}\right)$ & 0.539 & 0.451 & 0.414 & 0.482 \\
\hline$F(000)$ & 1272 & 1240 & 1336 & 1400 \\
\hline Crystal size (mm) & $0.30 \times 0.20 \times 0.18$ & $0.20 \times 0.17 \times 0.15$ & $0.40 \times 0.10 \times 0.03$ & $0.30 \times 0.20 \times 0.20$ \\
\hline$\theta$ Range for data collection $\left({ }^{\circ}\right)$ & $1.71-27.50$ & $1.71-27.50$ & $1.16-27.50$ & $1.66-27.50$ \\
\hline Reflections collected & 16316 & 17539 & 20109 & 21322 \\
\hline Independent reflections & $6759\left[R_{\mathrm{int}}=0.0294\right]$ & $6861\left[R_{\mathrm{int}}=0.0544\right]$ & $7643\left[R_{\mathrm{int}}=0.0623\right]$ & $7872\left[R_{\mathrm{int}}=0.0299\right]$ \\
\hline No. of observed reflections $[I>2 \sigma(I)]$ & 5845 & 4838 & 5835 & 6721 \\
\hline $\mathrm{Max} / \mathrm{min}$ transmission & 0.8944 and 0.8019 & 0.9280 and 0.7336 & 0.9280 and 0.7758 & 0.8621 and 0.7781 \\
\hline Data/restraints/parameters & $6759 / 0 / 335$ & $6859 / 0 / 335$ & $7642 / 0 / 361$ & $7871 / 0 / 398$ \\
\hline Goodness-of-fit on $F^{2}$ & 1.073 & 1.148 & 1.136 & 1.039 \\
\hline Final $R$ indices $[I>2 \sigma(I)]$ & $R_{1}=0.0330$ & $R_{1}=0.0794$ & $R_{1}=0.0595$ & $R_{1}=0.0318$ \\
\hline$R$ indices (all data) & $w R_{2}=0.0653$ & $w R_{2}=0.1526$ & $w R_{2}=0.1119$ & $R_{2}=0.0671$ \\
\hline$R$ indices (all data) & $R_{1}=0.0444$ & $R_{1}=0.1271$ & $R_{1}=0.0931$ & $R_{1}=0.0442$ \\
\hline & $w R_{2}=0.0690$ & $w R_{2}=0.1706$ & $w R_{2}=0.1276$ & $w R_{2}=0.0715$ \\
\hline Largest difference peak and hole (e $\AA^{-3}$ ) & 0.381 and -0.363 & 1.509 and -0.814 & 1.267 and -0.664 & 0.320 and -0.369 \\
\hline
\end{tabular}


Table 2

Selected bond distances $(\AA)$ and angles $\left(^{\circ}\right)$ for compounds $\mathbf{1}, \mathbf{2 a}, \mathbf{2 b}$, and $\mathbf{3}$

\begin{tabular}{|c|c|c|c|c|c|}
\hline \multicolumn{6}{|l|}{ Compound $\mathbf{1}$} \\
\hline Mo-N(3) & $1.762(2)$ & Mo-N(4) & $1.766(2)$ & & \\
\hline Mo-N(1) & $2.066(2)$ & $\mathrm{Mo}-\mathrm{Cl}$ & $2.3911(6)$ & & \\
\hline $\mathrm{N}(3)-\mathrm{Mo}-\mathrm{N}(4)$ & $108.36(8)$ & $\mathrm{N}(3)-\mathrm{Mo}-\mathrm{N}(1)$ & $92.17(7)$ & $\mathrm{N}(4)-\mathrm{Mo}-\mathrm{N}(1)$ & $103.89(7)$ \\
\hline N(3)-Mo-N(2) & $152.34(7)$ & $\mathrm{N}(4)-\mathrm{Mo}-\mathrm{N}(2)$ & $98.21(7)$ & $\mathrm{N}(1)-\mathrm{Mo}-\mathrm{N}(2)$ & $73.67(6)$ \\
\hline $\mathrm{N}(3)-\mathrm{Mo}-\mathrm{Cl}$ & $96.54(6)$ & $\mathrm{N}(4)-\mathrm{Mo}-\mathrm{Cl}$ & $107.96(6)$ & $\mathrm{N}(1)-\mathrm{Mo}-\mathrm{Cl}$ & $142.23(5)$ \\
\hline $\mathrm{N}(2)-\mathrm{Mo}-\mathrm{Cl}$ & $82.10(5)$ & $\mathrm{C}(8)-\mathrm{N}(3)-\mathrm{Mo}$ & $175.13(14)$ & $\mathrm{C}(20)-\mathrm{N}(4)-\mathrm{Mo}$ & $147.55(14)$ \\
\hline \multicolumn{6}{|l|}{ Compound $\mathbf{2 a}$} \\
\hline Mo-N(2) & $1.745(4)$ & $\mathrm{Mo}-\mathrm{N}(1)$ & $1.759(4)$ & Mo-C(32) & $2.219(6)$ \\
\hline Mo-N(4) & $2.376(5)$ & $\mathrm{Mo}-\mathrm{N}(3)$ & $2.070(5)$ & & \\
\hline $\mathrm{N}(2)-\mathrm{Mo}-\mathrm{N}(1)$ & $109.3(2)$ & $\mathrm{N}(2)-\mathrm{Mo}-\mathrm{N}(3)$ & $93.9(2)$ & $\mathrm{N}(1)-\mathrm{Mo}-\mathrm{N}(3)$ & $107.8(2)$ \\
\hline $\mathrm{N}(2)-\mathrm{Mo}-\mathrm{C}(32)$ & $95.0(2)$ & $\mathrm{N}(1)-\mathrm{Mo}-\mathrm{C}(32)$ & $105.5(2)$ & $\mathrm{N}(3)-\mathrm{Mo}-\mathrm{C}(32)$ & $140.2(2)$ \\
\hline $\mathrm{N}(2)-\mathrm{Mo}-\mathrm{N}(4)$ & $151.8(2)$ & $\mathrm{N}(1)-\mathrm{Mo}-\mathrm{N}(4)$ & $98.6(2)$ & $\mathrm{N}(3)-\mathrm{Mo}-\mathrm{N}(4)$ & $73.0(2)$ \\
\hline $\mathrm{C}(32)-\mathrm{Mo}-\mathrm{N}(4)$ & $81.2(2)$ & $\mathrm{C}(1)-\mathrm{N}(1)-\mathrm{Mo}$ & $148.6(4)$ & $\mathrm{C}(13)-\mathrm{N}(2)-\mathrm{Mo}$ & $177.4(4)$ \\
\hline \multicolumn{6}{|l|}{ Compound $\mathbf{2 b}$} \\
\hline Mo-N(2) & $1.761(3)$ & Mo-N(1) & $1.775(3)$ & Mo-C(32) & $2.169(3)$ \\
\hline Mo-N(4) & $2.403(3)$ & $\mathrm{Mo}-\mathrm{N}(3)$ & $2.078(3)$ & & \\
\hline $\mathrm{N}(2)-\mathrm{Mo}-\mathrm{N}(1)$ & $110.71(13)$ & $\mathrm{N}(2)-\mathrm{Mo}-\mathrm{N}(3)$ & $96.00(13)$ & $\mathrm{N}(1)-\mathrm{M} 1 \mathrm{o}-\mathrm{N}(3)$ & $111.97(12)$ \\
\hline $\mathrm{N}(2)-\mathrm{Mo}-\mathrm{C}(32)$ & $90.29(14)$ & $\mathrm{N}(1)-\mathrm{Mo}-\mathrm{C}(32)$ & $109.94(14)$ & $\mathrm{N}(3)-\mathrm{Mo}-\mathrm{C}(32)$ & 131.94(13) \\
\hline $\mathrm{N}(2)-\mathrm{Mo}-\mathrm{N}(4)$ & $156.18(12)$ & $\mathrm{N}(1)-\mathrm{Mo}-\mathrm{N}(4)$ & $93.07(12)$ & $\mathrm{N}(3)-\mathrm{Mo}-\mathrm{N}(4)$ & $72.86(11)$ \\
\hline $\mathrm{C}(32)-\mathrm{Mo}-\mathrm{N}(4)$ & $82.55(12)$ & $\mathrm{C}(1)-\mathrm{N}(1)-\mathrm{Mo}$ & $156.4(3)$ & $\mathrm{C}(13)-\mathrm{N}(2)-\mathrm{Mo}$ & $174.9(2)$ \\
\hline \multicolumn{6}{|l|}{ Compound $\mathbf{3}$} \\
\hline Mo-N(5) & $1.757(2)$ & Mo-N(4) & $1.762(2)$ & Mo-N(1) & $2.362(2)$ \\
\hline $\mathrm{Mo}-\mathrm{Cl}$ & $2.3834(5)$ & Mo-N(2) & $2.079(2)$ & & \\
\hline $\mathrm{N}(5)-\mathrm{Mo}-\mathrm{N}(4)$ & $110.39(7)$ & $\mathrm{N}(5)-\mathrm{Mo}-\mathrm{N}(2)$ & $104.36(7)$ & N(4)-Mo-N(2) & $97.71(6)$ \\
\hline $\mathrm{N}(5)-\mathrm{Mo}-\mathrm{N}(1)$ & $93.56(6)$ & $\mathrm{N}(4)-\mathrm{Mo}-\mathrm{N}(1)$ & $156.03(7)$ & $\mathrm{N}(2)-\mathrm{Mo}-\mathrm{N}(1)$ & $74.40(6)$ \\
\hline $\mathrm{N}(5)-\mathrm{Mo}-\mathrm{Cl}$ & $105.84(5)$ & $\mathrm{N}(4)-\mathrm{Mo}-\mathrm{Cl}$ & $92.17(5)$ & $\mathrm{N}(2)-\mathrm{Mo}-\mathrm{Cl}$ & $142.47(4)$ \\
\hline $\mathrm{N}(1)-\mathrm{Mo}-\mathrm{Cl}$ & $81.97(4)$ & $\mathrm{C}(11)-\mathrm{N}(4)-\mathrm{Mo}$ & $173.13(13)$ & $\mathrm{C}(23)-\mathrm{N}(5)-\mathrm{Mo}$ & $158.03(13)$ \\
\hline
\end{tabular}

and recrystallized from diethyl ether to afford the desired product. Yield: $1.23 \mathrm{~g}(81 \%)$.

\subsection{2. $\left.\left\{\mathrm{Mo}\left(\mathrm{NC}_{6} \mathrm{H}_{3} \mathrm{Pr}_{2}^{i}-2,6\right)_{2} \mathrm{Me}\left[\mathrm{NC}_{4} \mathrm{H}_{3}\left(\mathrm{CH}_{2} \mathrm{NMe}_{2}\right)-2\right]\right\}\right]$} (2a)

A $50 \mathrm{ml}$ Schlenk flask was charged with $20 \mathrm{ml}$ of diethyl ether and $1(1.00 \mathrm{~g}, 1.7 \mathrm{mmol})$ and cooled to $-78{ }^{\circ} \mathrm{C}$. To the solution, MeLi $(1.2 \mathrm{ml}, 1.4 \mathrm{M}$ in diethyl ether, $1.7 \mathrm{mmol}$ ) was added via syringe and stirred for $12 \mathrm{~h}$ after slowly warming up to room temperature. The mixture was filtered to removed lithium salt and the filtrate was concentrated and cooled to $-20{ }^{\circ} \mathrm{C}$ to afford deep red crystals, among which a very small amount of unidentified impurity was observed. Yield: $0.78 \mathrm{~g}(81 \%) .{ }^{1} \mathrm{H}$ NMR $\left(\mathrm{CDCl}_{3}\right): \delta$ $7.10(\mathrm{~s}, 6 \mathrm{H}$, aryl), $6.82(\mathrm{~m}, 1 \mathrm{H}$, pyrrole $), 6.14(\mathrm{~m}, 2 \mathrm{H}$, pyrrole), $4.16\left(\mathrm{~s}, 2 \mathrm{H}, \mathrm{CH}_{2} \mathrm{~N}\right), 3.53$ (sept, $4 \mathrm{H}, \mathrm{CH} \mathrm{Me}_{2}$ ), $2.84\left(\mathrm{~s}, 6 \mathrm{H}, \mathrm{NMe} e_{2}\right), 1.14\left(\mathrm{~s}, 3 \mathrm{H}, \mathrm{Mo}-\mathrm{CH}_{3}\right), 1.09(\mathrm{~m}$, $24 \mathrm{H}, \mathrm{CHMe}) \cdot{ }^{13} \mathrm{C} \mathrm{NMR}\left(\mathrm{CDCl}_{3}\right): \delta 152.0(\mathrm{~s}), 144.5$ $(\mathrm{s}), 136.7(\mathrm{~s}), 131.7\left(\mathrm{~d}, J_{\mathrm{CH}}=183 \mathrm{~Hz}\right), 126.2\left(\mathrm{~d}, J_{\mathrm{CH}}=\right.$ $160 \mathrm{~Hz}), 122.3\left(\mathrm{~d}, J_{\mathrm{CH}}=158 \mathrm{~Hz}\right), 109.4\left(\mathrm{~d}, J_{\mathrm{CH}}=167\right.$ $\mathrm{Hz}), 103.4\left(\mathrm{~d}, J_{\mathrm{CH}}=167 \mathrm{~Hz}\right), 64.2\left(\mathrm{t}, J_{\mathrm{CH}}=138 \mathrm{~Hz}\right)$, $49.2\left(\mathrm{t}, J_{\mathrm{CH}}=138 \mathrm{~Hz}\right), 28.1(\mathrm{~d}, 129 \mathrm{~Hz}), 24.1(\mathrm{q}$, $\left.J_{\mathrm{CH}}=126 \mathrm{~Hz}\right), 23.9\left(\mathrm{q}, J_{\mathrm{CH}}=126 \mathrm{~Hz}\right), 23.2\left(\mathrm{q}, J_{\mathrm{CH}}=\right.$ $126 \mathrm{~Hz})$.

\subsection{3. $\left.\left\{\mathrm{Mo}\left(\mathrm{NC}_{6} \mathrm{H}_{3} \mathrm{Pr}_{2}^{i}-2,6\right)_{2} \mathrm{Bu}\left[\mathrm{NC}_{4} \mathrm{H}_{3}\left(\mathrm{CH}_{2} \mathrm{NMe}\right)_{2}\right)-2\right]\right\}$} (2b)

A similar procedure had been applied as for $\mathbf{2 a} . \mathbf{1}$ (1.50 g, $2.5 \mathrm{mmol})$ and BuLi (1.0 ml, $2.5 \mathrm{M}, 2.5 \mathrm{mmol})$ were used. Yield: $1.36 \mathrm{~g}(88 \%) .{ }^{1} \mathrm{H}$ NMR $\left(\mathrm{CDCl}_{3}\right): \delta$ $7.05(\mathrm{~s}, 6 \mathrm{H}$, aryl), $6.79(\mathrm{~s}, 1 \mathrm{H}$, pyrroate), $6.08(\mathrm{~m}, 2 \mathrm{H}$, pyrroate), $4.03\left(\mathrm{~s}, 2 \mathrm{H}, \mathrm{CH}_{2} \mathrm{~N}\right), 3.56\left(\mathrm{~m}, 4 \mathrm{H}, \mathrm{CH} \mathrm{Me}_{2}\right)$,

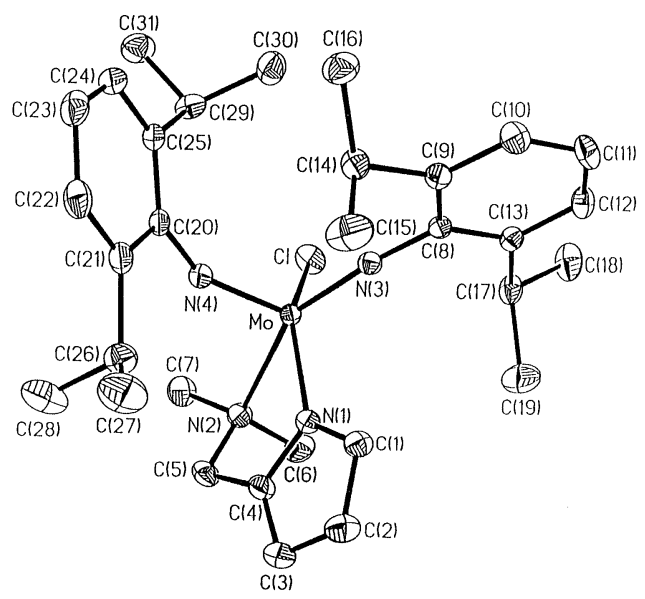

Fig. 2. The ORTEP plot of compound 1. Thermal ellipsoids are drawn at $50 \%$ probability and hydrogen atoms are omitted for clarity. 
Table 3

The comparison of bond distance and angle of five coordinate bis(2,6-diisopropylphenyl)imido complexes

\begin{tabular}{|c|c|c|}
\hline Complex & $\begin{array}{l}\text { Mo-N-C bond angle } \\
\text { and } \mathrm{Mo}-\mathrm{N} \text { bond } \\
\text { distance }\left({ }^{\circ} ; \AA\right)\end{array}$ & Reference \\
\hline $\begin{array}{l}\mathrm{Mo}\left(\mathrm{NC}_{6} \mathrm{H}_{3} \mathrm{Pr}_{2}^{\mathrm{i}}-2,6\right)_{2}- \\
\left(\mathrm{CH}_{2} \mathrm{SiMe}_{3}\right)^{-} \\
\left(\mathrm{Py}-2-\mathrm{CMe}_{2} \mathrm{O}\right)\end{array}$ & $\begin{array}{l}172.95,1.769 ; 152.52 \\
1.753\end{array}$ & {$[13]$} \\
\hline $\begin{array}{l}{\left[\mathrm{Mo}\left(\mathrm{NC}_{6} \mathrm{H}_{3} \mathrm{Pr}_{2}^{\mathrm{i}}-2,6\right)_{2^{-}}\right.} \\
\mathrm{Me}(\mu-\mathrm{OMe})]_{2}\end{array}$ & $\begin{array}{l}\text { 177.44, 1.756; 153.67, } \\
1.757\end{array}$ & [13] \\
\hline $\begin{array}{c}\mathrm{Mo}\left(\mathrm{NC}_{6} \mathrm{H}_{3} \mathrm{Pr}_{2}^{\mathrm{i}}-2,6\right)_{2^{-}} \\
\mathrm{Me}_{2}\left(\mathrm{PMe}_{2} \mathrm{Ph}\right)\end{array}$ & $\begin{array}{l}175.93,1.759 ; 151.90 \\
1.760\end{array}$ & {$[11 \mathrm{~b}]$} \\
\hline $\begin{array}{l}\mathrm{Mo}\left(\mathrm{NC}_{6} \mathrm{H}_{3} \mathrm{Pr}_{2}^{\mathrm{i}}-2,6\right)_{2}- \\
{\left[\mathrm{Py}\left(\mathrm{OCPh}_{2} \mathrm{CH}_{2}\right)_{2}-2,6\right]}\end{array}$ & $\begin{array}{l}164.78,1.760 ; 144.79 \\
1.771\end{array}$ & {$[14]$} \\
\hline $\begin{array}{l}\mathrm{Mo}\left(\mathrm{NC}_{6} \mathrm{H}_{3} \mathrm{Pr}_{2}^{\mathrm{i}}-2,6\right)_{2}^{-} \\
\quad \mathrm{Cl}\left[-\mathrm{C}\left(\mathrm{Me}_{2}\right) \mathrm{COOBu}^{\mathrm{t}}\right]\end{array}$ & $\begin{array}{l}158.58,1.730 ; 157.66 \\
1.754\end{array}$ & {$[15]$} \\
\hline $\begin{array}{l}\mathrm{Mo}\left(\mathrm{NC}_{6} \mathrm{H}_{3} \mathrm{Pr}_{2}^{\mathrm{i}}-2,6\right)_{2^{-}} \\
\quad \mathrm{Cl}\left[\mathrm{CH}\left(\mathrm{NMe}_{2}\right) \mathrm{COOEt}\right]\end{array}$ & $\begin{array}{l}171.10,1.745 ; 160.95 \\
1.753\end{array}$ & {$[15]$} \\
\hline Compound 1 & $\begin{array}{l}175.13,1.762 ; 147.55 \\
1.766\end{array}$ & This work \\
\hline Compound 2a & $177.4,1.75 ; 148.6,1.759$ & This work \\
\hline Compound $\mathbf{2 b}$ & $\begin{array}{l}174.9,1.761 ; 156.4, \\
1.775\end{array}$ & This work \\
\hline Compound 3 & $\begin{array}{l}173.13,1.762 ; 158.03 \\
1.757\end{array}$ & This work \\
\hline
\end{tabular}

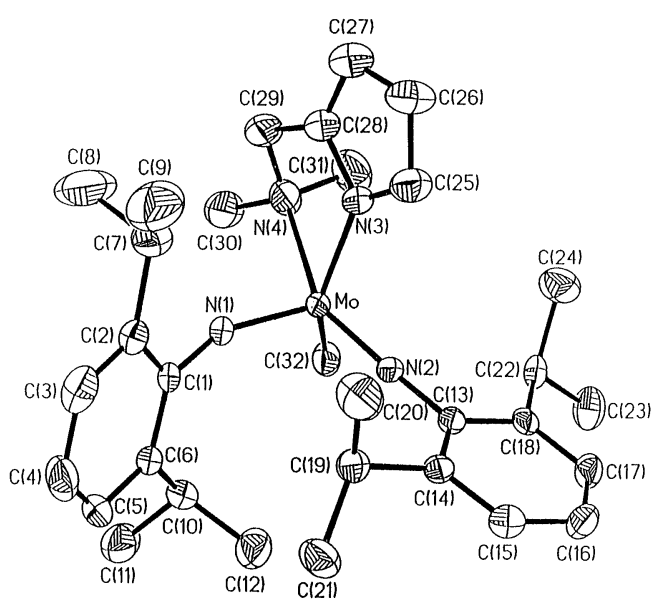

Fig. 3. The ORTEP plot of compound 2a. Thermal ellipsoids are drawn at $50 \%$ probability and hydrogen atoms are omitted for clarity.

2.77 (s, 6H, NMe $), 1.89$ (s, br, 4H, Mo- $\mathrm{CH}_{2} \mathrm{CH}_{2-}$ $\left.\mathrm{C}_{2} \mathrm{H}_{5}\right), 1.25\left(\mathrm{~m}, 2 \mathrm{H}, \mathrm{Mo}-\mathrm{CH}_{2} \mathrm{CH}_{2} \mathrm{CH}_{2} \mathrm{CH}_{3}\right), 1.01$ (m, $24 \mathrm{H}, \mathrm{CHMe}$ ), 0.85 (m, 3H, $\mathrm{Mo}-\mathrm{CH}_{2} \mathrm{CH}_{2} \mathrm{CH}_{2} \mathrm{CH}_{3}$ ). ${ }^{13} \mathrm{C}$ NMR $\left(\mathrm{CDCl}_{3}\right): \delta 151.6(\mathrm{~s}), 144.6(\mathrm{~s}), 136.8(\mathrm{~s})$, $132.2\left(\mathrm{~d}, J_{\mathrm{CH}}=183 \mathrm{~Hz}\right), 126.1\left(\mathrm{~d}, J_{\mathrm{CH}}=160 \mathrm{~Hz}\right), 122.4$ $\left(\mathrm{d}, J_{\mathrm{CH}}=153 \mathrm{~Hz}\right), 109.3\left(\mathrm{~d}, J_{\mathrm{CH}}=162 \mathrm{~Hz}\right), 103.4(\mathrm{~d}$, $\left.J_{\mathrm{CH}}=167 \mathrm{~Hz}\right), 64.3\left(\mathrm{t}, J_{\mathrm{CH}}=138 \mathrm{~Hz}\right), 52.4\left(\mathrm{t}, J_{\mathrm{CH}}=\right.$ $123 \mathrm{~Hz}), 49.4\left(\mathrm{q}, J_{\mathrm{CH}}=138 \mathrm{~Hz}\right), 37.8\left(\mathrm{t}, J_{\mathrm{CH}}=126 \mathrm{~Hz}\right)$, $29.1(\mathrm{t}, 123 \mathrm{~Hz}), 28.0\left(\mathrm{~d}, J_{\mathrm{CH}}=128 \mathrm{~Hz}\right), 23.8(\mathrm{q}$, $\left.J_{\mathrm{CH}}=126 \mathrm{~Hz}\right), 23.5\left(\mathrm{q}, J_{\mathrm{CH}}=126 \mathrm{~Hz}\right), 13.5\left(\mathrm{q}, J_{\mathrm{CH}}=\right.$ $124 \mathrm{~Hz})$.

\subsection{4. $\left\{\mathrm{Mo}\left(\mathrm{NC}_{6} \mathrm{H}_{3} \mathrm{Pr}_{2}^{i}-2,6\right)_{2} \mathrm{Cl}_{[}\left[\mathrm{NC}_{4} \mathrm{H}_{2}\left(\mathrm{CH}_{2} \mathrm{NMe}_{2}\right)_{2}-2,5\right]\right\}$ (3)}

A procedure analogous to that utilized for $\mathbf{1}$ was employed. $\mathrm{Mo}\left(\mathrm{NC}_{6} \mathrm{H}_{3} \mathrm{Pr}_{2}^{\mathrm{i}}-2,6\right)_{2} \mathrm{Cl}_{2}(\mathrm{dme})(1.00 \mathrm{~g}, 1.65$ mmol) and $\left[\mathrm{LiNC}_{4} \mathrm{H}_{2}\left(\mathrm{CH}_{2} \mathrm{NMe}_{2}\right)-2,5\right](0.31 \mathrm{~g}, 1.65$ mmol) were used. Yield: $1.01 \mathrm{~g}(92 \%) .{ }^{1} \mathrm{H}$ NMR $\left(\mathrm{CDCl}_{3}\right): \delta 7.07$ (s, 6H, aryl), 6.05 (s, 2H, pyrrole), 3.61 (m, br, $8 \mathrm{H}, \mathrm{CH}_{2} \mathrm{~N}$ and $\left.\mathrm{CH} \mathrm{Me}_{2}\right), 2.38(\mathrm{~s}, \mathrm{br}, 12 \mathrm{H}$, $\mathrm{NMe}$ ), 1.02 (s, br, 24H, CHMe $\left.)_{2}\right){ }^{13} \mathrm{C} \mathrm{NMR}\left(\mathrm{CDCl}_{3}\right)$ : $\delta 153.1(\mathrm{~s}), 145.5(\mathrm{~s}), 139.4(\mathrm{~s}), 128.2\left(\mathrm{~d}, J_{\mathrm{CH}}=160 \mathrm{~Hz}\right)$, $122.4\left(\mathrm{~d}, J_{\mathrm{CH}}=157 \mathrm{~Hz}\right), 106.8\left(\mathrm{~d}, J_{\mathrm{CH}}=169 \mathrm{~Hz}\right), 61.7$ $\left(\mathrm{t}, J_{\mathrm{CH}}=135 \mathrm{~Hz}\right), 47.4\left(\mathrm{q}, J_{\mathrm{CH}}=137 \mathrm{~Hz}\right), 28.2(\mathrm{~d}$, $\left.J_{\mathrm{CH}}=130 \mathrm{~Hz}\right), 24.2\left(\mathrm{q}, J_{\mathrm{CH}}=127 \mathrm{~Hz}\right), 23.4\left(\mathrm{q}, J_{\mathrm{CH}}=\right.$ $125 \mathrm{~Hz}), 15.2\left(\mathrm{q}, J_{\mathrm{CH}}=126 \mathrm{~Hz}\right)$.

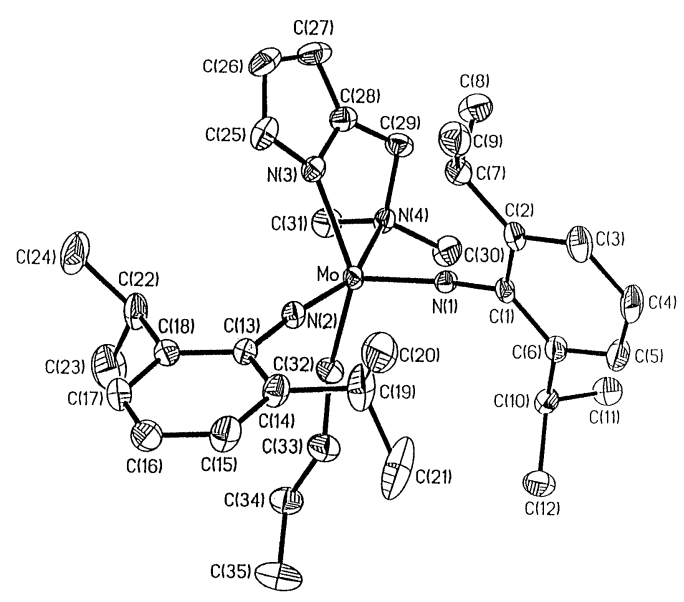

Fig. 4. The ORTEP plot of compound $\mathbf{2 b}$. Thermal ellipsoids are drawn at $50 \%$ probability and hydrogen atoms are omitted for clarity.

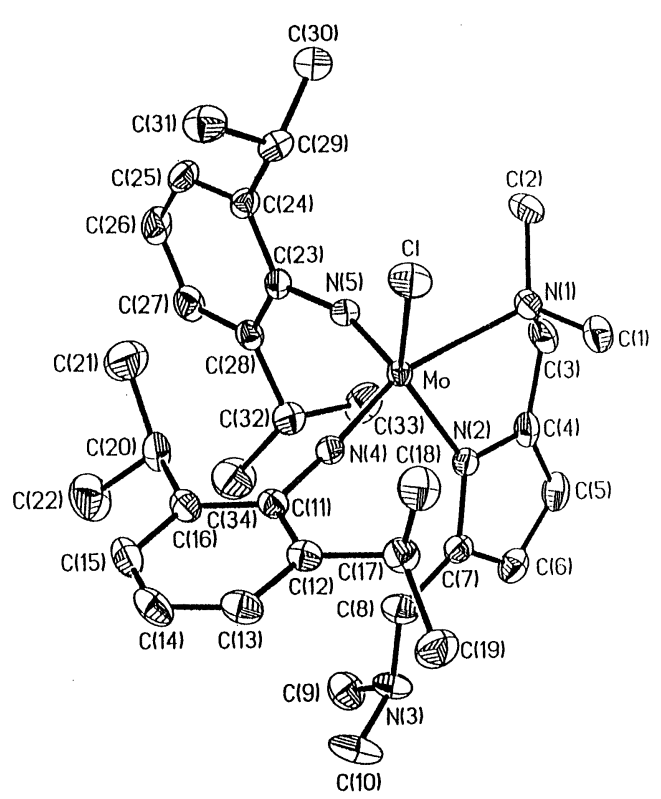

Fig. 5. The ORTEP plot of compound 3. Thermal ellipsoids are drawn at $50 \%$ probability and hydrogen atoms are omitted for clarity. 


\section{2. $X$-ray structure determination of compounds $\mathbf{1}, \mathbf{2 a}$, \\ $\mathbf{2 b}$, and $\mathbf{3}$}

The same procedures have been taken for the structural determination of compounds $\mathbf{1}, \mathbf{2 a}, \mathbf{2} \mathbf{b}$, and $\mathbf{3}$. The crystals were mounted on glass fibers using epoxy resin and transferred to a goniostat and cooled to $150 \mathrm{~K}$ under liquid nitrogen vapor. Data were collected on a Bruker SMART CCD diffractometer with graphitemonochromated Mo $\mathrm{K} \alpha$ radiation. An empirical absorption was applied and based on the symmetryequivalent reflections using the SADABS program. Using SHELXTL program on PC computer made the structure analysis. Structures were solved using the direct method and refined by full-matrix least-squares on $F^{2}$ values. Largest residual electron density for compounds $\mathbf{2 a}$ and $\mathbf{2 b}$, which are very closed to Mo atom, should result from the noise peak. The high $R_{1}$ value of 2a (0.0794) may result from the crystal quality. Non-hydrogen atoms were refined anisotropically. Hydrogen atoms were fixed at calculated positions and refined using a riding mode. The structure of compound $\mathbf{3}$ was disorder and the site occupancy of $\mathrm{N} 3, \mathrm{C} 9, \mathrm{C} 10, \mathrm{~N} 3^{\prime}, \mathrm{C} 9^{\prime}$ and $\mathrm{C} 10^{\prime}$ have been processed with 0.50 . The crystal data are summarized in Table 1.

\section{Supplementary material}

Crystallographic data for compounds $\mathbf{1}, \mathbf{2 a}, \mathbf{2 b}$, and $\mathbf{3}$ are available from the authors on request.

\section{Acknowledgements}

We are grateful to the National Science Council (Taiwan) for supporting this research and the National Center for High Performance Computing for data base search.

\section{References}

[1] D.E. Fjare, W.L. Gladfelter, J. Am. Chem. Soc. 103 (1981) 1572.

[2] M.A. Andrew, H.D. Kaesz, J. Am. Chem. Soc. 101 (1979) 7225.

[3] W.A. Nugent, R.L. Harlow, J. Am. Chem. Soc. 102 (1980) 1759.

[4] W.A. Nugent, J.M. Mayer, Metal-Ligand Multiple Bonds, Wiley Interscience, New York, 1988.

[5] For reviews see: (a) R.F. Jordan, Adv. Organomet. Chem. 32 (1991) 325. (b) H.H. Brintzinger, D. Fischer, R. Mülhaupt, B. Rieger, R.M. Waymouth, Angew. Chem., Int. Ed. Engl. 34 (1995) 1143. (c) P.C. Möhring, N.J. Coville, J. Organomet. Chem. 479 (1994) 1.

[6] (a) W. Herz, K. Dittmer, J. Am. Chem. Soc. 69 (1947) 1698; (b) H. Kim, R.L. Elsenbaumer, Tetrahedron Lett. 39 (1998) 1087.

[7] H. Drvs, A. Schmeiber, H. Hartung, U. Baumeister, Chem. Ber. 129 (1996) 853.

[8] J.H. Huang, P.C. Kuo, G.H. Lee, S.M. Peng, J. Chin. Chem. Soc. 27 (2000) 1191.

[9] J.H. Huang, H.J. Chen, J.C. Chang, G.H. Lee, S.M. Peng, Organometallics 20 (2001) 2647.

[10] H.H. Fox, K.B. Yap, J. Robbins, S. Cai, R.R. Schrock, Inorg. Chem. 31 (1992) 3287.

[11] A similar compound, $\left[\mathrm{Mo}\left(\mathrm{NC}_{6} \mathrm{H}_{3} \mathrm{Pr}_{2}^{\mathrm{i}}-2,6\right)_{2} \mathrm{Me}_{2}\right]$ exhibits multiple $\mathrm{C}-\mathrm{H} \cdots \mathrm{Mo} \alpha$-agostic interactions in solid state, which is not sustained in solution. See references (a) J.M. Cole, V.C. Gibson, J.A.K. Howard, G.J. McIntyre, G.L.P. Walker, Chem. Commun. (1998) 1829. (b) V.C. Gibson, C. Redshaw, G.L.P. Walker, J.A.K. Howard, V.J. Hoy, J.M. Cole, L.G. Kuzmina, D.S. De Silva, J. Chem. Soc., Dalton Trans. (1999) 161.

[12] (a) A. Bell, W. Clegg, P.W. Dyer, M.R.J. Elsegood, V.C. Gibson, E. Marshall, J. Chem. Soc., Chem. Commun. (1994) 2247; (b) C.G. Ortiz, K.A. Abboud, J.M. Boncella, Organometallics 18 (1999) 4253;

(c) U. Radius, J. Sundermeyer, Chem. Ber. 125 (1992) 2183;

(d) G. Casty, T.D. Tilley, Organometallics 16 (1997) 4746;

(e) A.C. Sullivan, G. Wilkinson, J. Chem. Soc., Dalton Trans. (1988) 53.

[13] J.A.M. Brandts, J. Boersma, A.L. Spek, G. van Koten, Eur. J. Inorg. Chem. (1999) 1727.

[14] V.C. Gibson, E.L. Marshall, C. Redshaw, W. Clegg, M.R.J. Elsegood, J. Chem. Soc., Dalton Trans. (1996) 4197.

[15] P.A. Cameron, G.J.P. Britovsek, V.C. Gibson, D.J. Williams, A.J.P. White, J. Chem. Soc., Chem. Commun. (1996) 737.

[16] (a) T.R. Cundari, Chem. Rev. 100 (2000) 807; (b) T.R. Cundari, J. Am. Chem. Soc. 114 (1992) 789. 